Olivera GE (2018) Reframing the figure of the sexual child/teen in Argentine cinema: Affect, sexuality and agency, Journal of Language and Sexuality, 7 (1), pp. 105-140. Available at: https://doi.org/10.1075/jls.17007.oli This article is under copyright. John Benjamins should be

contacted for permission to re-use or reprint the material in any form.

\title{
Reframing the figure of the sexual child/teen in Argentine cinema:
}

Affect, sexuality and agency

\author{
Guillermo Olivera \\ University of Stirling, Scotland, UK
}

\begin{abstract}
Drawing on a detailed analysis of a corpus of three key Argentine post-2000 films in which the figure of the child as a sexual/gendered being is central, this article explores three core affective dimensions of the processes of queer child/teenage relational subjectivation. Firstly, it discusses the queer shameful or injured selves of LGBTIQ children/teens as nevertheless being able to open up new spaces of affective performativity that can potentially challenge gender/sexuality norms and boundaries. Secondly, it addresses early queer antagonism associated with the configurative role of the 'closet space'. Thirdly, emerging processes of peer solidarity and alliances arising from queerness, and non-heteronormative sexualities more generally, are identified and subjected to a political reading in terms of different forms of relationality, mobility and agency. By examining the verbal as well as the visual dimensions of the referential and affective messages inscribed in these films, the analysis attends to both their articulated and non-articulated meanings.
\end{abstract}

KEYWORDS: children/adolescents, sexuality, sex/gender, intersex, queer, affect, relationality, Argentine Cinema

This article approaches the representation of queer children and adolescents in post2000 Argentine Cinema through the theoretical lenses provided by discourse analysis and queer theory, and by focussing on the concepts of affect and infantile sexuality. My theoretical framework posits that both negative and positive affects are crucial for the early constitution of the queer subject. As far as negative affects are concerned, my analysis sheds light on queer shame as the affective kernel of early queer subject formation insofar as sexual-gender-originated shame is not any affect. Rather, queer shame and sexuality-gender based injury have a paramount triple role with regard to the very formation and emergence of LGBTIQ people as sexual beings in a homophobic, transphobic and interphobic world. 
Firstly, by providing an initial, originating space for the queer self, queer shame seems to operate at the level of the very affective conditions for their very making as subjects. Secondly, it reveals or catalyses structural antagonisms that are at the basis of the 'non-relational relation' that constitutes them in relation to the heteronormative adult world and its normative familial ideologies. Thirdly, by being profoundly relational, shame and shaming enable -rather than obstruct- peer queer relationality, and are potentially capable of bringing about the emergence of positive affects in processes of early queer subjectivation.

In each of the films studied here, I have identified one core object around which shame and secret, through the dynamics of the open secret, are structured: 'male-male kissing' in Glue (2006); 'boy's menstruation' in El último verano de la Boyita/The Last Summer of La Boyita (2007); and the 'double sexual participation' of the intersex body as 'monster' in $X X Y$ (2007). Positive affects -such as teen-teen bonding, shared pleasure and solidarity- on the other hand, are analysed as intrinsically connected with the relational, shared experience of shame, but most crucially, as emerging from these prepubescent and pubescent protagonists' infantile sexuality, that is to say, affects emerging from co-experiencing non-heteronormative sexual forms of eroticism that are capable of challenging gender binaries, boundaries and norms. Through the analysis of filmic visual and verbal data, I then demonstrate how these positive affects pave the way to, crucially, child/teen queer agency through verbal nameability (of the object of shame) as well as through the visual acting out of shame and shaming.

Child-child and teen-teen relationality is what allows for these linguistic processes of naming and these bodily processes of acting out to emerge, and thus, it is through this peer relationality that queer subjectivation and agency can start to take 
place, and have a place, for LGBTIQ children and teens. My analysis of the filmic corpus hence pays attention to both visual language and linguistic expression, the latter encompassing lexis (i.e. what is articulated by coded linguistic meaning) as well as phoné (i.e. what exceeds coded meaning within actual speech or voice, such as timbre, tone, musicality, silence, (non)hearing and what is (un)heard). My aims are to closely analyse the referential message conveyed by verbal speech (film dialogue) and cinematic language in the three films in question, as well as to go beyond the latter two and engage in finer-grain affective meaning.

\section{The films}

The three films discussed here are part of a broader movement and textuality of post2000 Argentine filmmaking, a moment marked by a shift according to which the child and teen protagonists as sexual beings engaged in processes of becoming, in their own right -rather than just a symbolic or allegorical figure of something else- have become central.

\section{Theorizing the sexual(ized) child/teen in Argentine Cinema}

The socially marginalised, criminalised and institutionalised child/adolescent has been a recurrent figure in Argentine cinema since the late 1950s, and it is within this frame that the first instances of non-normative child/teenage sexualities appear on the Argentine screen: the sexualised child as mere victim of rape, abandonment, abuse, 
confinement, deprivation, destituteness, and so forth. ${ }^{1}$ If sexuality and/or negative affects have traditionally played a key role in the cinematic representation of the victimisation of marginalised minors, in post-2000 Argentine films the depiction of queer childhoods and adolescence moves beyond the previous frame of institutionalised 'deviance' imposed on them, by opening up the scope of representation to a much wider range of social groups, settings and processes of subjectivation, including the rural/urban, sexuality/gender junctions and inter-class interactions. These cinematically reframed childhood and teen sexualities can thus be read as rhetorical sites where the figure of the child -or its reversed 'corrupted version'- is undone. These diverse forms of undoing the Figure of the Child (Edelman 2004) tell us stories about children and adolescents embodying queer beings or processes of queer becomings (Giffney 2008). This is an important shift in Argentine cinema because the queer child/teen as a sexual being in his/her own right -rather than a figure representing something else- seems to have become central to a wider corpus of $21^{\text {st }}$ century movies in which child/teenage sexuality is the focus: the on-screen sexual(ised) child/teenager victim is now a 'queer child/adolescent' that gains in agency and subjectivation processes.

By being capable of actualising certain lines of flight, these queer children and teens, far from representing the (heteronormative) Figure of the Child or its 'corrupted', inverted version, can be read as 'sinthomosexuals' (Edelman 2004) in themselves, hence subjects of queer becomings in their own right. Rather than allegorizing the nation's ills, I propose that these sexualized children should be read as real symptoms of homo-, trans- and inter-phobic ideologies and contexts, in line with other scholarly

\footnotetext{
${ }^{1}$ Examples of this mode of representation are to be found in films such as El secuestrador/The Kidnapper (Torre Nilsson, 1958) ,Crónica de un niño solo/Chronicle of a Boy Alone (Favio, 1965) or El polaquito / The Polish Boy (Desanzo, 2003).
} 
readings of cinematic childhoods as symptomatic (Triquell 2012) rather than metaphorical or allegorical. These lines of flight are inscribed in queer children and teens' negative and positive affects, and it is this affective dimension that allows for new connections between children's and teens' bodies and their spaces, which, in turn, render possible different forms of mobility that resist familial-teleological narratives by 'making them flee' from heteronormative futurity.

In these three films, children and teens tend to respond to family/adult society's queer-phobic environment and discourse by embodying negative affects revolving around self-isolation, idleness, and withdrawal as the marks of antagonism understood as 'non-relational relation"2 (Mihkelsaar 2015: 54-56). This finds its affective expression in the 'intersubjective breakdowns' (Zamostny 2012: 198-201) that recur in the three films analyzed in this article, between the queer children/teens in question and their families. However, if the central negative affect that psychologically expresses and socio-culturally configures the latter political operation (i.e. antagonism) is (queer) shame, it is my contention that shame as a negative affect, far from just revealing the antagonistic anti-relational, operates as actually enabling relationality amongst children and/or teens. Furthermore, queer connections and alliances let emerge (earlier) infantile sexuality as a way of shaping positive affects in queer children going through latency and pubescent teens who would otherwise be expected to be heteronormatively engaged

\footnotetext{
${ }^{2}$ This refers to the heterogeneous element that threats the very constitution of a discursive order or an identity, so not any difference, but an antagonistic difference that symbolically threatens an existing hegemonic order, albeit making, at the same time, this order possible. This is achieved by establishing a relationship with this antagonistic force, even if this is a completely negative relationship, that is to say, a non-relational relation with the 'antagonistic other'. Queer children and adolescents are such elements, insofar as their difference antagonistically threatens the very symbolic existence of the heteronormative family. In signalling the heteronormative family's own symbolic limits, a non-relational relation is established between queer children/adolescents and their families. This form of constitutive, negative relationality finds its affective expression in an array of negative, relational affects, of which (queer) shame seems to be the dominant one. Shame is, by definition, relational (Probyn 2005, Sedgwick 2003).
} 
in developing genital resolutions to their sexuality. Bodily connections, music, childchild (or teen-teen) interactions and voice (phoné, silence), can thus be read as expressions of infantile sexuality pointing to the affective, rather than the developmental adult-genital. Object-less autoeroticism finds here a connection with the affectiverelational, rather than with the (heteronormative) genital.

\section{Glue}

Glue (historia de un adolescente en medio de la nada)/“'Story of an Adolescent in the Middle of Nowhere"), is the story of Lucas, a 16-year-old boy who lives a rural area in the desert-like Patagonian plateau. The film concentrates on his meanderings during the summer, always riding his bike in solitude, with his headphones on as if escaping from his dysfunctional family. For Lucas, however, it is also the summer in which he discovers sex and eroticism with his friends Andrea and Nacho, falling in love with the latter.

Lucas's interactional behaviour shows a detachment and withdrawal from his dysfunctional family, especially his father, to whom he does not speak. Whenever his father asks him questions, or proposes something to him, the teenage son simply does not answer back and physically withdraws from the conversation. Lucas's negative affects towards his family are expressed through emotional withdrawal, idleness and self-isolation from them. These negative affects is what prompts his constant wandering and movement triggered by a line of flight that goes outwards from his family home and is signalled and paced by the music from his headphones. Rock music and drugs feature as a de-territorializing line of flight to the urban: the boys have a rock band, compose 
and constantly listen to music, and their first gay sexual experience (shared masturbation) takes place in the city of Neuquén: this is the homoerotic climax of the narrative in which the two boys are under the effects of glue. The significance of this typically adolescent drug use -a line of flight that also marks with its intensity the main homoerotic scene- is evidenced by the title of the film. There is also a crucial bisexual sex scene shared by the three teens in the toilet of a night club. Finally, the closing scene underscores mobility by showing the three protagonists on bikes 'riding around' and 'bike-wandering' in a construction site, a scene significantly edited with the song Let me go wild as non-diegetic soundtrack.

In their respective escape flights from their families, the three teenagers -Lucas, Nacho and Andrea- encounter one another, allowing positive affects to come through the erotic connection and playful relationality between the three teen protagonists. Early teenage sex and (bi)sexuality feature as the key motives that relationally drives them out of their families.

In fact, Lucas's interactional work can be analysed as a pendulum between, on the one hand, his communicative, relational interactions with his teen peers -Nacho and Andrea, later his sister-and, on the other hand, his antagonistic, 'non-relational relation' with his parents, particularly his father. Lucas remains, for most of the film, argumentative and non-cooperative in his interactions with his parents: he talks in a hostile manner to his mother, and his ninguneo or non-responsive silence towards his father can be read as a relationship of non-return.

Within the aforementioned teen-teen positive attachments beyond the family, there is a prevailing unspoken homoeroticism between Lucas and Nacho, which is visually recurrent but verbally unacknowledged. The main driver of this homoerotic, 
vital force -intense pubescent libido is the renaissance of the infantile sexual drive (Freud 2016)- comes from Lucas, for whom the focal point of intensity is the malemale kiss. There is of course considerable bodily contact between the two male teen protagonists, through wrestling, shared masturbation, and so forth, but it is from Lucas's agency that he drives the actions towards the homoerotic kiss. For instance, the first time that the building site appears onscreen, is as the landscape witness of their homoerotic wrestling ${ }^{3}$ that starts with Nacho teasing Lucas - by hitting him with a slingand culminates in a tongue kiss that Lucas 'forces' on Nacho, after a breathing control game as a result of which Lucas actively gets the prize of the kiss:

(1)

-L: Abrí la boca

-N: Aj ...ajjjjjj ajjjjj [can't breath]

While the wrestling and the thrill of the chase continues (after $\mathrm{N}$ manages to escape), L's voiceover states:

- L Mañana viene mi viejo ${ }^{4}$

-N A qué?

L: No sé, a cenar

N: No estaban peleados? [while the boys are still fighting] [...]

L: Yo me tengo que escapar

N: Por qué?

L: Porque viene mi viejo, boludo

(1)

-L: "Open your mouth"

-N: Aj...ajjjjjj ajjjjj [can't breath]

While the wrestling and the thrill of the chase continues (after Nacho manages to escape), Lucas's voiceover states:

$-L$ "My dad is coming tomorrow"

$-N$ "What for?"

$L$ : "I don't know, to have dinner"

$N$ : [while the boys are still fighting] / "Had you not fallen out?"

$[\ldots]$

\footnotetext{
${ }^{3}$ A building site features for the first time as background playground of this first homoerotic scene; we shall see its recurrence in the film's ending providing a narrative resolution: this time, the three teens are playing in a cinematic representation of 'Playland', the (queer?) infantile utopia (Agamben 1993).

${ }^{4}$ This is the only verbal line in a very long sequence of silent wrestling culminating in male-male kissing: problem of masculinity inseparable from the 'absent father figure', or at least the issue of fatherhood.
} 
$L:$ "I'll have to run away"

$N$ : "Why?"

$L$ : "Because my dad is coming, you prick."

The shot of the kiss as culmination of wrestling cuts into another shot of them two, this time topless, as the only human presence in the immensity of the blue-skied Patagonian plateau, an iconography that cites the gaucho male dyad in the solitude of the pampas, a national mythical model of male bonding and friendship in Argentina. This is followed by a sequence in which the only female teen protagonist, Andrea, appears for the first time in the movie, significantly introducing the iconic figure of the Gauchito Gil, a local pagan sanctity from gaucho folklore. The teens then proceed to their eroticised childlike game that follows a binary code only shared by the two boys and is based on the movements of mouth and hands (open/closed). The game consists in Lucas asking (in English) 'open or closed?' while showing his hands performing movements of opening or closing, but the clue of the game is actually in his mouth (whether his mouth is open or closed), so it is basically about misleadingly communicating with his hand what he is actually doing with his lips. At the same time, the three teenagers are drinking milk (milky chocolate). If sensual sucking is, for early Freud (2016: 40), the very 'model of the infantile sexual manifestations' as it allows the subject to relive the pleasurable connection lips/warm milk, what is at stake in this scene is infantile sexuality, and not just pubescent/adult genital(ised) desire or the death drive. It is my contention that through these relational and communicative bodily connections (lips/milk, lips/hands), we can read infantile sexuality and hence the affective message in the film.

The fact that the male teenagers enact with their hands the same kinetic code that their lips simultaneously perform, is quite telling of the main affect associated with male-male kissing: shame. Even if the message is misleading, the code is present in a 
bodily displaced way, from lips to hands. If the 'real message' to be deciphered is actually given by the very same movements involved in kissing and sucking -the clue is in the lips- the fact that this message is 'hidden', non-verbalised as such, and instead, displaced and playfully dramatised, points to the crucial affect that this acting out game is ambivalently concealing and revealing: male-male kissing as shame. The game points of course to the teens' desire for a sensorial connection through kissing ${ }^{5}$, but interestingly it is the female teen the one who is initially excluded from a kissing game -normatively understood as young girls' romantic fixation- that in this movie seems to be controlled and driven by boys, as an expression of their sexual drive rather than of a 'longing for romance'.

After these scenes, Lucas's voice-over erupts, in a self-reflective mode:

(2)

Qué diferencias hay entre besar a un hombre y besar a una mujer? [...] Los hombres tienen barba. ${ }^{6}$ Si no fuera por eso, sería lo mismo? [voice-over: subjective rock soundtrack listened by Lucas through his headphones, repeating the line 'just one kiss', once and once again] [.] Quiero viajar. [.] Por qué los hombres no lloran? [This is immediately followed by Lucas in his room and his father's off-screen voice]

(2)

"What's the difference between kissing a man and kissing a woman? [...] Men have beards. If it wasn't because of this, would it be the same? [voice-over: subjective rock soundtrack listened by Lucas through his headphones, repeating the line 'just one kiss', once and once again] [.] I want to travel. Why is it that men don't cry?" [This is immediately followed by Lucas in his room and his father's off-screen voice]

\footnotetext{
${ }^{5}$ As we shall see, the significance of kissing and smoking for Lucas in Glue relates to early Freud's (2016) idea of children whose 'individual constitution' imply an intensified erogenous significance of the lips, and are, thus, later in life, inclined to 'perverse kissing', drinking or smoking.

${ }^{6}$ This relates to how Lucas introduces Nacho at the beginning of the film, through the former's voiceover account of the latter's more developed masculinity, as more hairy: he is curious about "the hair that Nacho must have in his armpits", because his "are just a few and blond", which he immediately relates to sexuality or object of desire: 'What would Nacho think about when he has a wank?"
} 
Early Freud's (2016 [1905]) ideas are helpful here in order to understand the role of the male-centred kiss in this film: kissing for Freud is 'perversion' par excellence-perverse sexuality, hence Sexuality tout court-, insofar as it points to (infantile) sexuality itself, that is, to the sexual drive, rather than to later genital fixations and reductions that tend to normatively develop with the emergence of adult/pubescent sexuality (i.e. the Oedipal, genital, heteronormative resolution of the castration complex). It also connects with the strong links that Freud (2016) (noted in van Haute \& Westerink 2016) had made between perversion and hysteria -the type of neurosis that most directly and clearly expresses sexuality and, by the simultaneous showing and ostensive concealment of the sexual drive in the negative form of the bodily symptom. If we consider that in Western cultures it is the female body that is usually 'hysterized' (i.e. sexualised) (Foucault 1990: 126-139), it is interesting to note that in this film "hysteria" is taken up by the male-male kissing: male pubescent sexuality ${ }^{7}$, otherwise genitallycentred, is thus (re)sexualised by means of homosexuality and bisexuality (i.e. in psychoanalytical terms, through 'perverse' -i.e. non-functional or non-intergenitalforms of sexuality).

In Glue, the inscription of the non-genital sexual drives is in young males, and the mouth as non-genital erogenous zone with its opening/closing movements -which are not, in essence, phallic- are ironically the main (non-romanticised) obsession of these young male pubescents with sex. Penetration, for instance, does not seem to be their main aim in their fulfilment of sex: Lucas's voice-over clearly states one of his main concerns with sex: A las chicas les gusta en serio chupar pijas?/“Do girls really like to suck cocks?". Masturbation, on the other hand, does feature in the film, but not

\footnotetext{
${ }^{7}$ In Freud, pubescent sexuality is adult sexuality because it's genitally centred.
} 
within a phallic-genitally centred frame and despite Lucas's explicit introductory declaration at the beginning of the film: "This summer I have to fuck". This desire for fucking, in the fined grained narrative discourse of the film, becomes a longing for (male-male) sensual kissing, and more broadly, bodily contact. Whilst the former is, from the very outset, verbalised through voice-over narration and reiterated in the teens' dialogues, the latter is, significantly, only acted out without ever crossing the threshold of the verbal enuncive mode.

Bodily contact and verbal interactions between the teens bring about shared positive affects to the communication breakdowns of their family contexts, thus 'moving them through' the middle of nowhere or 'desert of nothing' (Leap 1999: 264; 1996: 125-139) in which they live. Let us recall the eloquent subtitle of the film, 'story of an adolescent in the middle of nowhere': in both a symbolic and literal sense, the Patagonian plateau is, physically, a desert. However, Lucas's fully relational and frequently verbal interaction with Nacho presents moments of crisis, which are usually negotiated through non-verbal communication: by emerging in its limits, affective, nonarticulated message shows the limitations of spoken language. Music plays an important role in these moments of non-verbal negotiations of 'communication breakdown' or silence: this is the case, for instance, in the first re-encounter after the two boys had spent a night in bed together watching porn and masturbating themselves. The last time they had seen each other was the morning when Nacho was hurriedly leaving the flat where they had slept together, in silence and with a strong feeling of shame, while Lucas was prompting him to stay by asking him "not to be a prick" (no seas forro). The first re-encounter of the pair after this 'shameful situation' has a sense of awkwardness conveyed by the pair's absolute silence as neither of them seems to be able to utter a 
word after their shared event. However, the camera takes them both in a medium twoshot, uniting them in their 'unspeakable shameful experience' while sitting by the train tracks and only having recourse to 'improvised shared music' to communicate with one another. Recalling Lucas's previous quiero viajar/'I want to travel', homoeroticism is giving him, like music, a line of flight. In a kind of exclusively 'phatic' moment of communication, the pair of teens just repeatedly tap on the railway tracks, as if trying to communicate to each other, with stones from the road, their symbolic and interactional presence 'musically', whilst unable to verbalise or linguistically elaborate, or indeed name, what had just happened between them. Through rhythm and sound, tapping here creates signals rather than symbolic or iconic signs ${ }^{8}$ : it is in the interactional inbetweenness of these signals without a code -without a referential content or a societally shared aesthetic symbolic meaning within them- where the affective, bodilybound message is mutually co-created. Interestingly, the immediately following scene will find the two male teens dancing together in the discotheque -where they had gone with mutual female friend Andrea: this scene is crucial because it culminates in the boys ultimately communicating through kissing, with the vicarious intermediation of Andrea. In fact, it is through Andrea that Lucas gets to kiss Nacho:

(3) Lucas (to Andrea): -Pasáselo a Nacho Lucas (to Andrea): - "Pass it on to Nacho"

Now, the deferrals and delays with regard to male-male kissing can be read as both pubescent repression of infantile sexuality and expression of queer shame. Shame as

\footnotetext{
${ }^{8}$ Music and silence discursively operate here as affective phoné, that is to say, as unarticulated voice, rather than articulated voice (lexis) (Lyotard, 1997).
} 
one of the core affects in this film could be analysed as focussed on male-male kissing as the primary object of shame - especially for the protagonist Lucas- rather than male same-sex attraction or even same-sex sexual practice such as shared masturbation. Whilst the masturbation scene could be construed as physiological need, and whilst strong homosocial friendship or Platonic love could be interpreted as a psychological need associated to affective developmental processes -both are usual episodes in the process of so-called sexual maturation and 'experimentation' amongst pubescent teensthe kiss, on the contrary, has an entirely different role and symbolic meaning in this erotic economy, because of its privileged relation to early male socialisation shame. While same-sex sexual practices, homoeroticism ${ }^{9}$, and homosocial friendship can be justified by need or even by positive affects (i.e. homosocial bonding, masculine sexual pleasure, pride, or camaraderie), male-male kissing seem to be in the film one of the primary objects of shame. Evidence of this is the fact that Lucas and Nacho feel so close to the feeling of shame associated to male-male kissing, that they seem to need the acting out of the 'male-male kissing event' through playing, in at least three instances.

Firstly, the acting out of kissing through the open/closed game that metaphorically re-enacts and cites the act of kissing by duplicitously displacing it to the double scene of the open/closed hands running parallel to the open/closed mouth; secondly, the 'threesome game' that uses Andrea as intermediary in the passage of the kiss between the two boys (Pasáselo a Nacho/'Pass it on to Nacho"); thirdly, the kiss as

\footnotetext{
${ }^{9}$ During the mouth game scene, while Andrea is not present, there is also a playful acting out of anal sex that is only shared by the two boys. Lucas teases Nacho, by putting on the mask of the catwoman, while also playing sexual games with a puppet, focussing on the penis and anus (le pica el culo/"his ass itches", while rubbing the puppet's bum): Lucas is using here the puppet's own hands for its anal penetration. Significantly, it is in this scene the teenagers arrange a weekend encounter in Lucas's father flat for just the three of them, but only the boys will be able to make it. Thus, the scene prepares the ground for the shared masturbation scene between Lucas and Nacho, that would take place immediately after.
} 
victorious 'violation' of Nacho's mouth by Lucas, once Nacho has been reduced to breathlessness and immobility, as the loser-victim of the wrestling. Acting out through games, playful behaviour and dramatisation is eloquent of the excessive proximity to shame (Probyn 2005: 149-156), to the shame that male-male kissing might be representing for teenage males during their early pubescent years: heteronormative masculinity in the process of gender identification plays a key role here -not equivalent to pubescent female gender identification processes-insofar as male-male kissing seems to condense a major threatening symbolic value for the heteronormative male identification processes of pubescent boys.

Towards the end of the film, when there seems to be a promise of family reconciliation -the nuclear family decides to have a weekend reunion in a tent, by a lake- Lucas gets out of the tent as soon as he gets up to watch the pink flamingos on the lake -since John Waters' Pink Flamingos (1972), a cinematic symbol of antagonistic queer disgust, and not of disgust as repressive affect as conceptualised by Freud (2016). A strong affect frames again the queer anti-familial ending of this film, while Lucas resumes his listening to his headphone music and giving his back to the family tent: the only one who joins him is his teenage sister, with whom Lucas shares his headphones, thus opening up his own line of flight world to her. Like the flamingos that fly away from the lake, Lucas stays away from the family tent, and the camera cuts from this lake family scene to the final scene of the film that gives it a narrative resolution: the three teens against the landscape background of the building site, introduced by Lucas's voice-over: 
Cuando uno está con la familia se comporta diferente que cuando uno está con amigos.

"When one is with one's family, one behaves differently than when one is with friends."

\section{El último verano de la Boyita / The Last Summer of La Boyita}

El último verano de la Boyita tells the story of two queer children -pre-pubescent tomboy Jorgelina and intersex-trans pubescent Mario- establish a strong affective and erotic connection during a summer spent together in the countryside. Mario was born as genetically female, but grew up as a boy due to his anatomical appearance: Mario's 'over-sized' clitoris and excess of masculine hormones, along with the less medicalised rural milieu and the labour needs of a working-class family of farmers to have a man to take care of tough rural tasks (Solomonoff, in Martin \& Shaw 2012) explain why he was raised as a boy. As in Glue and $X X Y$, I focus my analysis of this film on the language of bodily alliance and connection between two sexual misfits: Jorgelina (the queer girl) and Mario (the gonadically female but hormonally masculine child, raised as a boy). ${ }^{10}$

Mario's parents are in denial. This denial is ultimately based on a family pact of silence, whose violation is of course punishable: pubescent Mario is physically beaten up by his father, and his mother cries about the emergence of the biological fact (female chromosomes and genitalia) -the so-called 'truth' of sex (Foucault)- adding up to the economy of blame of a coming out situation that is family-defined as punishable. The only relational and affective support that Mario receives is from his child friend

\footnotetext{
${ }^{10}$ Deborah Martin (2013: 34, 35), in a lucid reading of this film, analyses these attachments as queer 'pairing'.
} 
Jorgelina, younger than him, still under 'latency'. They share a great deal of child play, some of it with erotic overtones. They mostly connect through masculine child-playing: wrestling in the countryside, horse riding, going to the river. Jorgelina is the only one to whom Mario confides his 'secret': Mario had been bleeding for four or five months, something that he would soon discover through Jorgelina, is called 'menstruation', as illustrated in the dialogue transcribed below:

(5)

-J: [referring to her sister Luciana] Porque está insoportable desde que le vino.

-M: Qué cosa?

-J: Ya sabés. El asunto. Andrés. El que viene una vez por mes. [in Spanish, 'Andrés' rhymes with 'month': indirect naming and musicality is introduced here at the point of inception of the co-construction of secret]

$-M$ [pause in conversation: silent countershot of $M$, staring at $J$ pensive, deep in thought]

-J: [very emphatically, clearly pronouncing each phoneme] La mens[:::]truación. La sangre.

- $M$ [pause in conversation: silent countershot of $M$, again staring at $J$ pensive, as if preoccupied]

- J: Me contó mi papá que vas a correr. Con el Yayo.

- M: Ahá. Sí, el 14.

-J: Puedo ir?

-M: Sí, si querés.

(5)

-J: [referring to her sister Luciana] "Because she has become unbearable since it came to her."

-M: "What is it that came to her?"

-J: You know. The thing. Andres, the one who comes once a month. [in

Spanish, 'Andres' rhymes with 'month': indirect namimg and musicality is introduced here at the point of inception of the co-construction of secret]

-M [pause in conversation: silent countershot of $\mathrm{M}$, staring at J pensive, deep in thought]

-J: [very emphatically, clearly pronouncing each phoneme]

"Mens[:::]truation. The blood."

-M [pause in conversation: silent counter-shot of $\mathbf{M}$, again staring at $\mathbf{J}$ pensive, as if preoccupied]

- J: "My dad told me that you'll ride in the race. On Yayo." 


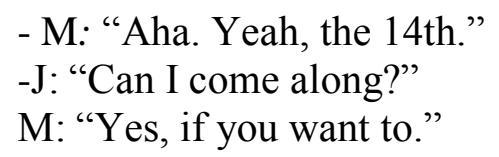

This is a key scene that features the initial interactional co-construction of menstruation/bleeding as secret between the two children, insofar as Jorgelina unknowingly offers Mario, for the first time, a way of naming his non-shared experience. This child-child relational intervention through nameability is crucial for providing Mario with some affective meaning to his 'desert of nothing' (Leap 1996, 1999). The scene ends with the two children riding away together on their respective horses, as if foreshadowing the film's ending: the transformative line of flight $^{11}$ and deterritorialization (Patton 2000: 2, 8-9; 103-108) produced in and by the alliance between the two, and Mario's final escape.

The cooperative co-construction of Mario's sexual secret as child-child alliance is consolidated in a subsequent scene in which Mario confides with Jorgelina about his intimate lived experience of the changes in his body. After jointly looking at some anatomy books with pictures of male and female genitalia, we see Mario inspecting his own genitalia on his own, while still in his room. The camera immediately cuts to a close-up shot of a 'natural hole' -a hole-shaped nest made of sticks that actually Jorgelina is looking at, thus positioning us from Jorgelina's visual perspective (in her role of the film's focaliser character). Mario interrupts her looking at this 'natural hole' that could be read, in the context given by the narrative and dialogue, as a 'natural'

\footnotetext{
${ }^{11}$ Martin (2013) reads these transformative lines of flight as brought about by the connections between children protagonists and animals, and actualised in the becoming-animal of children in these films. In a different reading of these audiovisual textualities, I would rather argue for the child/child or teen/teen attachments as the crucial assemblages that are capable of setting in motion those processes of deterritorization and becoming.
} 
landscape metaphor for Mario's anatomy. The following conversation starts, thus, with the background of the countryside (trees, birds):

(6)

-Mario: Yo no soy como la foto.

-Jorgelina: Es que estás cambiando. Es la adolescencia.

-Mario: Yo no soy [...] normal.

-J Yo tampoco soy muy normal.

-M [Eso no fue nadie [...] No es una cicatriz.

[silence; $M$ whispers something in J's ears: the secret-telling scene is visibly

and explicitly enacted here between the two children without the audience being able to access its content]

-J A mi abuela le salen bigotes [...] Igual me gustas así.

(6)

-"Mario: I am not like the photo.

-Jorgelina: It's because you are changing. It's adolescence.

-Mario: I am not [...] normal.

-J: I'm not very normal, either.

-M: That was not anybody's fault [...] That's not a scar.

[silence; $\mathrm{M}$ whispers something in J's ears: the secret-telling scene is visibly and explicitly enacted here between the two children without the audience being able to access its content]

-J: My grandmother has a moustache [...] All the same, I like you the way you are."

Interestingly, this non-scar will become a really marked scar after a wound perpetrated

by Mario's father on his face later on, once his secret is out, thus performing the

violence of the closet as a 'double-edged sword' (Sedgwick 1994). 'I still like you the way you are' is how the pre-pubescent child's response to Mario's sharing his object and motive of shame, giving a non-judgemental, loving frame to the co-construction of the secret, thus displacing the now shared, relational shame to a positive affect. In fact, immediately after this interactional exchange, Jorgelina shows, while on her own, that she has fallen in love with Mario. While immersed in the swimming pool on her own, she repeatedly calls his name in a dream-like fashion ('Mario!'), while the musical 
score that recalls their joint riding, juxtaposed with the diegetic sound of her environment -the sound of water and birds- takes up the foreground of the soundtrack. This soundtrack serves as sound bridge -subjective auricularization- to scenes showing Mario performing masculine duties in the farm as well as riding the horse at high speed -clapped in admiration by the rest of the children and his parents-as he is preparing for the race.

In contrast with these positive affects and relationality established between the queer children characters, the antagonistic 'anti-relational relation' emerges in the relationships established between children and the adult members of their families. Although Jorgelina has a good rapport with her father, there is a 'communication breakdown' in this adult-child relationship, as of course, there is one as well between Mario -suffering in silence- and both his parents. Once his secret is out and he has been examined by Jorgelina's father -a physician-, the scene in which Jorgelina asks the latter about Mario's condition is particularly eloquent about this adult-child 'antirelational relation':

(7)

-J: Qué le pasa a Mario?

-J's father: A ver [.] todos tenemos una glándula que produce hormonas masculinas.

-J (ears blocked off, so her father's voice is blocked for the audience, too) -J's father: En el caso de Mario hay un exceso de esas hormonas [que hacen que parezca un varón]; (hardly audible because of Jorgelina's humming) [.] porque genéticamente tendría que ser [mujer?] (while humming, the shot-countershot shows her father on a chair looking down at Jorgelina sitting on the floor -so, at a lower spatial level- looking up at him). The camera immediately cuts to a long landscape shot of two horses in the immensity of the pampas as background, while we hear Jorgelina's voice-over whispering her 'Dios te salve María' secret pray.

(7)

“-J: What's the matter with Mario? 
-J's father: Let's see [.] we all have a gland that produces masculine hormones -J: ears blocked off, so her father's voice is blocked for the audience, too -J's father: In Mario's case there is an excess of those hormones [that make him look like a male hardly audible because of Jorgelina's humming] [.] because genetically he should have to be [female?] (while humming, the shotcountershot shows her father on a chair looking down at Jorgelina sitting on the floor-so, at a lower spatial level- looking up at him). The camera immediately cuts to a long landscape shot of two horses in the immensity of the pampas as background, while we hear Jorgelina's voice-over whispering her 'God save thee Mary' secret pray."

The scientific explanation provided by Jorgelina's father is actively blocked off by herself: she covers her ears with her own hands as if not wanting to listen to her father as the voice of natural science's regulatory authority -biological referentiation as the imposed referential message- leaving the audience also without the explanation, as we can only hear the humming that the filter of her hands is interposing between her father's voice and us: auricularization is here, as in most of the film, from Jorgelina's perspective as the audience is visually and aurally positioned from the child's point of view by director Julia Solomonoff (in Martin \& Shaw 2012), in an 'heterospective' choice (Powrie 2005: 350-352). Immediately afterwards, Jorgelina goes away and utters, once on her own, a Catholic prayer, clearly going against the religious mandate of her own family unit (she belongs to a Jewish family). Jorgelina's isolating behaviour can be read as the affective manifestation of a more constitutive antagonism that actually relates, even if negatively, queer children and their parents.

Lyotard (1997) has elaborated on this strong link between the audible - phonéand the affective in children in terms of the infant's inability to hear the adults' articulated discourse or 'lexis', that is to say, its semantic content or referential message: “From the adults' phrases, they [the in-fans] cannot hear anything. [...] phoné "makes up stories" to the discourse, in the lexis. Phoné crushes discourse's ears, or it blocks 
them off.' ${ }^{12}$ (139-140) This phoné -those voices that resonate in children's ears, that is to say, what they can hear, which is not the same as noise ${ }^{13}$ is nothing but pure affectivity deprived of any reference (semantics) and of any direction or 'addressedness' (pragmatics) as the latter two features are what defines any articulated discourse (lexis). This non-articulated voice that is audible in phoné is also part of discourse, and children are particularly perceptive of it, insofar as it is a manifestation of objectless primary narcissism as defined by early Freud (Lyotard 1997). In other words phoné -voices' timbres, tonemes and musicality as well as silence- are discursive: they do not just express affects, but rather, are in themselves (objectless, a-referential) affects. ${ }^{14}$ That is why, when Jorgelina stays witnessing her father's description of Mario's 'problem' as one of 'excess of masculine hormones', she shuts down, she hears nothing but a numb humming: she had already said to him that he is not good at explaining things, to which her father answers that this is because 'you don’t listen'. So, why does Jorgelina not listen to adults, even to those with whom she has a good relationship with, like her own dad? Jorgelina's non-hearing of her father' normative biological science applied to

\footnotetext{
${ }^{12}$ My translation.

${ }^{13}$ The concept of 'noise' refers to the merely external, physical hurdle that obstructs communication from the outside, according to a cybernetic model that defines communication as transparent and deprived of any opaqueness. Phoné, on the contrary, is the affective dimension of discourse, and as such, it is not external to it, but inheres in discourse as its constitutive non-transparent excess: if through discourse's lexis, human beings enunciate and communicate with each other, by bringing opaqueness into discourse, phoné is the manifestation of their psyche, of their affects. According to Lyotard (1997: 136), phoné is 'identical' to affect: 'phoné is affect [in itself] inasmuch as the latter is a signal of itself' (my translation). ${ }^{14}$ Phoné as affect does not represent, or indeed articulate, anything. This is because the affective is what emerges in all that is unarticulated in discourse, which in Foucauldian analytical terms, corresponds to power as that which is not stratified, but which does however explain the very emergence of articulated discourse. If articulated discourse is always stratified as either visibilities or verbally enunciated statements, power -similarly to affect as suggested by Leap (2017), and notwithstanding their differences- is what remains in excess and cannot be coded or 'fully contained' (Leap, 2017) within the boundaries of (verbal or visual) regimes of stratification or articulation. Fully unstratified and irreducible to what is represented (i.e. stated and/or (un)seen), power, like affect, is nothing but relational, otherwise defined as 'the thought of the outside' (Deleuze, 2006). By potentially engaging many bodies, albeit incorporeal in itself, impossible to be owned or possessed (by any individual or group) and uncontainable in any stratified representation or indeed by any code, affect has been defined, like Foucauldian power, as fundamentally relational: 'Affect inheres in the capacity to affect and be affected' (Chen, 2012: 11).
} 
Mario is, thus, discursive: her father's (un)heard lexis becomes, in the child ears, through humming, not noise, but rather, affective and discursive phoné. According to Lyotard (1997: 136), phoné is the manifestation of the human psyche, of our affects: in this sense, phoné (in this case, Jorgelina's 'translation of scientific parlance' into humming) does not 'represent' affects, because it is 'identical' to affect: 'phoné is affect [in itself] inasmuch as the latter is a signal of itself' (my translation). By exceeding 'representation' or Vorstellung, phoné is, thus, the manifestation of affect as understood by Blackmann \& Venn (2010) in their critique of representational thinking, and further discussed by Christina Schoux (2017) in this special issue of $J L S:$ phoné as affect points to that 'excess', 'intensity' or environmental 'flood' (Schoux, 2017) that cannot be contained by the representational work of language or sight.

As Lucas's headphones in Glue and or Alvaro's ones in $X X Y$, Jorgelina's hands are figuring here queer antagonism understood as the 'non-relational relation' (Mihkelsaar 2015) that is at the limit of language and subject constitution (Laclau \& Mouffe 1985). In the case of queers, whilst the 'positive relational' tends to take place outside the family realm -communities such as LGBTIQ peers, or other communities where class, gender and ethnicity intersect with sexuality- the non-relational relation takes place in the family of origin (in the early stages of queer subject formation). Discursive and unarticulated phoné provides a channel for the affective mise-endiscours of such an antagonistic relation, even if the latter is still unable to enter the threshold of enunciation, that is, the threshold that marks the passage between pure language to speech (Agamben 1993) through articulation. Phoné is the matter that exceeds both phonology and phonetics, because it is not 'dismountable' in phonemes, it cannot be broken down in a chain of distinctive units or articuli. Clear examples of 
phoné in the data analysed so far are supra-segmental traits: Jorgelina's subjective humming, her rhyming and over-pronunciation of the word 'menstruation', Mario's silence, Lucas's and Nacho's verbal silence while tapping on the rail tracks: all these examples are tokens of purely affective meaning, be them negative or positive. By pointing, in semiotic terms, to the purely material level of manifestation, the matter of the plane of expression (Barthes 1985: 45-46) that has not become a distinctive phoneme or a 'substance of expression' in Hjelmslev's (1971) terminology, phoné and silence do not only express, but are in themselves (objectless, a-referential) affects. ${ }^{15}$

Child agency here is inextricably linked to children's enhanced sensitivity to phoné within the broader context of their hypersensorial capacity that Metz (1982) relates to the peculiar disposition of the cinematic viewer as 'all-perceiving subject'. In Solomonoff's film, this sensorial disposition materialises in Jorgelina's capacity to perceive what the adults cannot see, and to ask questions accordingly, in response to her perceptions $^{16}$ : these questions are, in turn, points of inception for new forms of relational interaction -that is to say, interactions whose agency stems from the child's privileged, hyper-sensitive point of view- and make the narrative go forward. The naiveté of the content of Jorgelina's questions does not undermine her agency: rather than with knowledge, her agency has to do with her capacity to see and hear, and her curiosity, that leads her to ask questions. As noted by director Julia Solomonoff (in

\footnotetext{
${ }^{15}$ The affective load that the in-fant/in-fans finds in phoné is an unarticulated signal, which from a semiotic viewpoint, means that although it has not entered the threshold of articulation (enunciation), it is certainly part and parcel of discourse and of (unarticulated) voice; hence it is part of meaning-making (sense but not signification proper through a symbolic or iconic sign). Phoné is therefore to be found neither at the formally signifying, phonological level nor at the distinctive, phonetic level of analysis: in contrast to the latter two, it is at the proto-semiotic level of the signal/signability that phoné/musicality and silence are discursive.

${ }^{16}$ Instead of denying or repressing perceptions, child agency lies precisely in this capacity to act upon their sensorial overdevelopment (as opposed to adult's typically more limited sensorial abilities) by asking questions (that implicitly acknowledge those perceptions) and/or acting on reality and social relations.
} 
Martin \& Shaw 2012), curiosity, visual and aural pleasure, and candid openness to the world around her seem to be the dominant affects in Jorgelina, against what would be expected from a female child during latency (Freud 2016: 70-73): shame and disgust as products of repression.

In this regard, Freud (2016) maintains that inhibitions and repression concerning sexuality such as shame or disgust are greater in little girls and they take place earlier than in boys, and puberty brings about an even starker contrast between sexual libidodriven boys, and the re-enforcement of repression in pubescent girls. This does not seem to happen in tomboy Jorgelina, even if she is still going through latency and is younger than Mario: curiosity rather than repression-based shame or disgust seem to prevail in the former. By contrast, repression is features quite clearly in feminine girl Luciana and in the other queer pubescent/teen characters of the films analysed in this article (including gay male ones): Mario in The Last Summer..., or Alvaro in XXY. In the cases of Glue's Lucas and Nacho, shame and repression tend to affect homoerotic activity they do it but they don't talk about it- and particularly, their male-male kissing. Shame has, thus, one could say, a different role in queer childhood and puberty, particularly with regard to how non-heterosexual sexualities interrelate with gender.

Jorgelina's questions -as responses that acknowledge what she perceivestrigger processes of narrative transformation and relational becomings in the characters, especially in Mario and his relationship with his parents. His family's grudging and violent acknowledgement of his gonadic status is, effectively, the result of Jorgelina's relational intervention that triggers the crisis and the conflict that would eventually lead 
to Mario's hiding away and final escape. ${ }^{17}$ In fact, Jorgelina is the first character who sees Mario's bleeding in the film. In a sequence that starts by Mario not wanting to bathe in the river with her, Jorgelina prompts him to speak:

(8)

- J: Por qué no te querés meter? / Why do you not want to get into it?

-M: Es traicionera el agua. / The water is treacherous.

-J: Es por eso? Te duele? Te pegó tu papá? / Is it because of that? Is it sore? Did your dad beat you up?

Mario does not answer Jorgelina's question, but they bond quite strongly, and even erotically as they ride together on the same horse -Jorgelina as Mario's 'pillion'- very closely attached to each other: their low body parts (genitals?) rubbing against each other's, while Mario holds her very tightly with his arms against his own body. In this scene, they commune in riding together as they become one in movement. Immediately after the ride, Jorgelina sees blood on the horse's saddle, and this is when Mario's secret first comes out. The agonistic conflict between closetedness and coming out that the narrative from this point onwards will dramatise -the very core of queer antagonism- is a consequence of the questions that this initial visual perception triggered in Jorgelina:

(9)

-J Tenés sangre. Te debés haber cortado con el tronco. Vamos a ver a mi papá.

-M No necesito doctor.

-J: Mario, en serio. Estás sangrando.

$-\mathrm{M}:[.] \rightarrow$ [noticeable pause/silence] Me voy a lavar. / I'm gonna wash myself.

\footnotetext{
${ }^{17}$ This is the expression of the antagonism (non-relational relation) that constitute the very self of queers in a transphobic, interphobic and homophobic world. In this case, the transphobic, interphobic and homophobic world is represented by the ideology reproduced by a working class, rural family. I am not talking of evil here, but about a societal ideology (that happens to be reproduced by a family of peasants who love their son).
} 
The following shot cuts from the open air countryside to Mario's room; Mario lying on his bed:

-J: Estás bien?

-M: Sí.

-J: Te traigo un té? Dale?

-M: Bueno. [.] Si la ves a mamá, no le digas.

[J keeps the secret in the following scene in the kitchen with M's mother] -J: Te sigue sangrando? [.] Es el Yayo, no?

-M: Sí.

-J: Estas seguro de que no querés que te vea mi papá?

M: [.] Debe ser 'la sangre'.

$\mathrm{J}: \mathrm{Si}$, te raspaste.

-M La menstruación [rising tone, but not too rising: ambiguous tone between a question and an affirmation]

-J: [..] [smiling] No, eso solo le viene a las chicas.

-M Igual no le cuentes a nadie.

$\mathrm{J}$ : [sad, worried look, first looking down towards Mario's lower body, then Jorgelina ritualistically swears promise to Mario by kissing her own fingers]

(9)

“-J: You've got blood. You must have cut yourself with the trunk. Let's go and see my dad.

-M: I don't need a doctor.

-J: Mario, seriously. You're bleeding.

-M: [.] $\rightarrow$ [noticeable pause/silence] I'm gonna wash myself.

The following shot cuts from the open air countryside to Mario's room;

Mario lying on his bed:

-J: Are you OK?

-M: Yes.

-J: Shall I bring you a cup of tea? Fancy some?

-M: OK [.] If you see my mum, don't tell her.

[J keeps the secret in the following scene in the kitchen with M's mother]

-J: Is it still bleeding? It's Yayo, isn't it?

-M: Yes

-J: Are you sure that you don't want my dad to see you?

M: [.] It must be 'the blood'.

$\mathrm{J}$ : Yes, you scratched yourself.

-M: The menstruation. [rising tone, but not too rising: ambiguous tone between a question and an affirmation]

-J: [..] [smiling] No, only girls get that.

-M: All the same, don't tell anybody."

J: [sad, worried look, first looking down towards Mario's lower body, then Jorgelina ritualistically swears promise to Mario by kissing her own fingers] 
This scene would directly lead to the relational, secret-driven and trust-building scene analysed above, in which Mario confesses to Jorgelina his own self-perception as 'not being normal', as well as showing her, his 'non-scar'. Interactional agency here is produced through nameability (Leap 1999), and only achieved by Mario through his relationality with Jorgelina: the bleeding experienced from his 'non-scar' becomes, then, 'his menstruation'. Mario assertively adopts this term to name his secret bodily experience, and this is later queerly referred to by Jorgelina as la menstruación de los varones/ "boys' menstruation".

Subsequent camera work concentrates on blood, conveying to the audience 'bleeding' as the main visual experience in the (silent) sequence of shots that follows: chicken bodies' bleeding, Mario and the farmers cutting whole cow bodies. In opposition to all these visually violent butchery, blood-oozing scenes, in which a sense of cutting and mutilation prevails, the immediately subsequent scenes show the strong connection between the pair, not just through mutual bodily contact -rubbing each other as they ride together- and touch-based attachment, but through erotised seduction, in which the erotically charged, adolescent-like (scopophilic) pivot of the gaze surfaces the screen: Mario appears now as an unfolding figure of beautified, eroticised seduction before Jorgelina's eyes. As 'spectacle' for the pleasure of the younger girl's look, Mario shows himself in an acrobatic masculine prowess standing on top of his horse, in an acrobatic demonstration of his horse-riding skills and physical mastery over his horse as beauty addressed to Jorgelina: this is clearly not infantile autoerotic play (Freud 2016), but adolescent relational eroticism, that is to say, objectual, driven by desire, and directed to a (queer) other. In this visual sequence, the pair interact in silence, by exchanging eroticised (loving?) looks. It is interesting to note that it is only after this 
erotically bonding scene -mediated by fantasy, desire and the gaze, rather than just their bodily attachment established earlier- that Mario starts confiding with Jorgelina about what he is secretly experiencing in his own body.

Mario's response to familial inter- and trans-phobia is escape, a line of flight that is marked by his horse-riding and the images of birds in the sky: the film ends in a parallel montage between Mario riding away on his horse after the race and a birds' flock $^{18}$ collectively migrating against the background of the blue summer sky. The birds' visual metaphor of relational flight is narratively enacted by Jorgelina as the only human being accompanying Mario in his escape. As the film's narrative resolution, they both share their naked bodies immersed in the river: Mario lets Jorgelina undress him, and she takes his corset off for the first time. The intimacy of the queer childrenoutcasts is only achieved in the open nature, away from the closeting, familial farm and rural settlement.

\section{$X X Y$}

$X X Y$ tells the story of 15-year-old intersex Alex and her family, who decide to move away to a Uruguayan coastal village (Piriápolis) in order to protect her from urban inter/transphobia at home in Buenos Aires. The film focuses on five crucial days in which they receive the visit of a family friend doctor who would assess the viability of a surgical intervention to 'normalise' Alex as female. Ramiro, the surgeon, comes with his family including his sensitive 16-year-old son Alvaro. Alvaro bonds with Alex and,

\footnotetext{
${ }^{18}$ The singing of birds features in most of the diegetic sound that conveys the countryside environment in the film. The background acoustic presence of birds through singing is noteworthy.
} 
after having sex with her, discovers her intersex condition, along with his own pleasure of being penetrated. Alex is then assaulted and visually victimised by a group of male teenagers after she was outed by her school friend Vando. Towards the end, she receives support from her teenage friends Vando, Roberta and Alvaro, and the only adult that stands up for her is Kraken, her father.

Ultimately, what can bring about Alex's adolescent agency are the positive affects implied in (queer) teen-teen bondings with Alvaro, Roberta and Vando, but also negative affects such as shame and shaming -the antagonistic core of her queer self. If shame and shaming are the individual and relational affects that reveal the societal closet's violence around Alex's intersex body, they ultimately find their relational expression in Alex's acting out her traumatic, victimizing assault -what has been described as a 'visual rape' (Zamostny 2012) by three macho-acting teenagers- through her aggressive behavior against Alvaro at the end of the film.

\subsection{Visual space: Queer utopias framing heterotopias of visibility}

Let us first identify certain scenes that point to queer connections, relationality and alliances between the two shame-constituted teen(age) protagonists: intersex Alex and bullied gay Alvaro. As has been pointed out by Zamostny (2012: 198-201), their respective responses to shame are 'intersubjective breakdown', withdrawal and selfisolation: Alex is from the very beginning of the film visually represented as a prey in her cage-like bedroom as if behind zoo bars and Alvaro cuts himself off from his social environment through his constant use of headphones. In this context of communication breakdown between queer pubescent teens and their families, the sea in $X X Y$ features as the recurrent background landscape for their moments of encounter, thus actualising and 
giving a place to reciprocity and queer relational potential: intimate, affect-driven, these are scenes in which the adolescents are able to surpass the generalised disconnection and 'communication breakdown' that tend to prevail in the film. Scenes that exemplify this point are the shared music and dancing scene after Alex had removed Alvaro's selfisolating headphones from his ears as well as the subsequent scene in which Alex offers Alvaro a pendent bearing a turtle's tag with a unique serial as a gesture and gift that bonds the pair in queer siblinghood, or towards the end, the intimate farewell of the pair by the sea, in a two-shot (from behind) that visually and symbolically approximates the two teenagers as 'a potential couple'.

These glimpses of queer utopia had been anticipated by some purely contemplative images of the desert-like sea, deprived of any human presence, at least in two scenes, as we shall see below. If these sea shots bear a symbolic, universalising function pointing to the utopianism of '(pure) life' and infinite possibility and potentiality, narratively, they hold a more concrete anticipatory as well as transitional role in Alex's trajectory of self-discovery. These shots could thus be read as standing in for the empty spaces opened up by the 'time-image' (Deleuze 2005), and narratively, they work as non-subjective, action-devoid, delaying and deferring transitions between, on the one hand, the family scenes featuring the recurring adults' (hetero)normative discussions around the 'urgent imperative' of Alex's surgical normalisation, and on the other hand, the (queer) teenage affective alliances.

The highly significant sea shots that I have identified are two. Firstly, towards the beginning of the film, the shot of the calm, brightly lit sea introducing for the first time to the audience Alex's topless androgynous body in the intimacy of her bed, playing with a lizard by her room's window -which opens up to the infinity of the sea- 
whilst she is getting rid of her hormonal feminising tablets. Secondly, nearly half way through the film, a highly symbolic non-subjective shot of the stormy sea as 'pure landscape' is interposed with all its premonitory noise as background diegetic sound. The sudden insertion of the latter shot of the deserted sea is edited as foreshadowing the traumatic, shameful event that will later take place in the very same seaside -her 'visual rape' (Zamotsny 2012) - as well as announcing the trajectory of crisis of which this traumatic event is part of: Alex's fugitive drift away from her family's home -just after she had penetrated Alvaro and subsequently recognised herself in the mirror-as well as the actualization of her personal, transformative line of flight.

Through the first of the aforementioned sea-framed scenes, I propose to analyse the spatial depiction of the intersex body in the film as heterotopian. From a different perspective, the figure of utopia in $X X Y$ has been used by Deborah Martin (2013) to account for Alex's body, and its 'becoming-animal', in relation to a subsequent scene in which Alex is topless again, but this time actually immersed in the sea. In an understanding of the intersex body that conceptualises it in spatial terms as a utopian 'territory' which, as such, would enable it to be spatially figured as a 'site of becoming', Martin (2013: 38) maintains that

'[...] in the floating scene, in which she seems to find a rare peace and freedom, and where she communes with a large green lizard which wanders over the territory of her naked body, suggesting a queer becoming of Alex's undecidable, utopian body with that of the animal with overtones of monstrosity. In this way the film figures the intersex body as a site of becoming [...].'

If the intersex body might be visually figuring the utopian here, it is worth noting that this seemingly utopian body is (recurrently) represented as floating in the sea. Particularly in relation to this sea-framed second appearance of Alex's topless androgynous body, it is significant that this time she is immersed in it -the sea as 
landscape has become her lived environment as she is being watched from a distance by Alvaro's voyeuristic gaze from the beach, who plays, as it is often the case in the film, the role of the 'uninvited onlooker' ${ }^{19}$ These sea-framed scenes (Alex on her own and the sea) could be taken as examples of the primary narcissism of infantile sexuality -the role of the (sexual/life) drives when exploring her naked body- and could be read as representing narcissism as a dimension that so deeply inheres in queer utopias as understood by Muñoz (2009: 90): 'narcissism actually represents a way of reducing, not affirming, rigidity of self.' Most importantly, both such scenes are sea-framed and voyeuristic insofar as they focus on showing the intersex body as androgynous, but none of them intrude in Alex's genitalia.

However, it is my contention that the symbolic meaning of queer utopia in this film does not 'naturally' derive from the intersex body itself, but from elsewhere: it is its socially constructed context what loads the sea with queer relational meaning. This can be analysed at the level of both visual language and speech. In terms of film language, through the second, premonitory shot of the sea, the viewer is faced with the image of a dreamlike seashore and a dreamlike boat, an image that, in turn, also foreshadows the narrative crisis ${ }^{20}$ and conflict that the very (temporo)-spatial structure of the village as closet space (Brown 2000) will inevitably trigger: as in the Deleuzian time-image (Deleuze 2005), in this shot of the seashore, time is suspended at the same time as intensely felt. In these transitional shots, landscape takes over the screen space, and thus (cinema) space takes over both action and time by suspending the latter.

\footnotetext{
${ }^{19}$ The first time being when Alvaro was watching Alex examine her own body in the mirror immediately after she had anally penetrated him, as mentioned above.

${ }^{20}$ In these transitional shots, landscape takes over the screen space, and thus (cinema) space takes over time by suspending it. The sea shots also mark the heterochronic dimension of the film's narrative: a narrative of adolescence as rite of (sexual and gendering) passage, that is to say, a heterotopian narrative of crisis.
} 
If Puenzo's shots of the deserted sea figure utopian space, they may also be connected with what Deleuze (2005) has conceptualised as 'any space whatever'. Standing for empty spaces, these deserted images mark precisely those affectively significant moments of meaningless, insofar as their emptiness -space depleted into pure time, a mere 'time-image'- signals precisely that 'absence of [any] possible content' (Deleuze, 2005: 16) that characterises Alex's transitional journey to her own (non-binary) self. Their relative autonomy from the narrative, the very 'stasis' (Schrader in Deleuze, 2005: 15) of these sea-shots, point to utopianism as 'queerness in the making', queerness as a (post-gender) horizon (Muñoz, 2009) of non-binary desires yet to come. The utopian symbolic function of these sea-shots stems from their status of empty spaces that are potentially able to 'reach the absolute as instances of pure contemplation' (15): they are like Burch's 'pillow-shots' (Burch in Deleuze, 2005: 16), which, by means of their transitional 'suspension of human presence' (273), render possible the characters' as well as the viewers' connection with the inanimate (i.e. the sea, beach and woods as landscape, the water as dominant environment).

The sea shots also mark the heterochronic dimension of the film's narrative: a narrative of adolescence as rite of (sexual and gendering) passage, that is to say, a heterotopian narrative of crisis (Foucault 1986, 1998). The role of the boat is particularly significant in its sheer heterotopian/utopian ambivalence: if the boat is where Alvaro came to Alex's (seaside) village, it is also the vessel that transports the three teenage attackers to the shore where they visually abuse Alex. Following Foucault's exemplary conception of ships as heterotopias par excellence insofar as they hold 'dreams', the boats in $X X Y$ figure the space that makes thinkable the possibility of queer love and friendship -as in the bondings Alex/Alvaro- within and beside the 
closet, as well as, in their very heterotopian ambivalence (Johnson 2006: 80),

representing at the same time the vehicle that makes possible an intersex-phobic assault. Its political, dislocating ambivalence (Laclau 1990) lies in its evoking imagination and dreams, whilst simultaneously indicating the always-imminent invasive threat of the closet-like proliferating 'secret' as its displaced traumatic core. The traumatic Real -the event as the sight of that which must/should not be seen- comes from a boat in $X X Y$ : in an incident that can be analysed as 'visual rape' (Zamostny 2012), the violent, violating look of the macho boys assaulting Alex condemns her to an unsolicited compulsory visibility. The same sight also leaves in a boat: this time, at the end of the film, in Alvaro's eyes, when he leaves in a boat.

Following this line of reading, if the sea tends to bear a highly symbolic, universalising utopian function in the film ${ }^{21}$, the closeted intersex body is, by contrast, represented as fragmentary -lacking an organic or symbolic unity-and heterotopian. This, in fact, defies utopianism as a given attribute to the intersex body: Alex's body is an actually-existing site that allows for the physical coexistence of contradictory and incompatible symbolisations. The film critically addresses the two dichotomic poles to which the intersex body has traditionally been attributed: either symbolised as the bodily site of biological perfection or as a token of abject monstrosity. The former construction is critically exemplified by Alex's father's utopian view as he almost entomologically narrates Alex's birth as the origin-event that provides the necessary perfect(ed) originary past -the myth of originary unity- to his utopian vision and

\footnotetext{
${ }^{21}$ As argued before, the sea features as witnessing moments of queer utopia. What 'queer' specifies here in 'queer utopia' is articulatory work: it specifies utopias as the unusual, singular, performative articulation between universal values (the sea as 'landscape of wish' and dreams beyond the horizon [Muñoz, 2009]) with the queer as the shameful particular.
} 
narrative of her, not unlike the narrative behind his collection of sea creatures as 'perfect animals', one might add:

(11)

Kraken (to Ramiro): - Alex nació azul. Tardó cuarenta minutos en respirar. [...]A los dos días nos ofrecieron operarla. [...] Suli [la madre de Alex] estaba asustada. Yo la convencí para que no le hiciéramos nada. Era perfecta, desde el primer momento en que la vi, perfecta. Kraken (to Ramiro): - "Alex was born blue. [...] It took her forty minutes to breathe. [...] Two days later, they offered us that she be operated on. Suli [Alex's mother] was scared. I was the one who persuaded her that we did not do anything to Alex. She was perfect, from the very first moment that I saw her, just perfect." 22

Kraken's discourse represents utopia as the narrative of origins (or the originary) and the logics of the beneath and behind (Sedgwick 2003: 8), against the dominant, normative utopian discourse of a two-gendered society represented in the movie by Alex's mother and surgeon Ramiro's medical narrative of femaleness through mutilation (i.e. the heteronormative discourse according to which the sex/gender binary defines utopia as a normative future-bound logic of the beyond). These two forms of essentialising utopias -origin and telos, beneath and beyond-differ, both of them, from queer utopia as the 'logics of the beside' (Sedgwick 2003: 8). ${ }^{23}$ Between the former two repressive modes of utopia, Alex seems to be engaging in a queer, post-gender utopia whose articulation could only take place in her relational potential of queer teenage bondings within a heterotopian environment. This process of subjectivation is able to

\footnotetext{
${ }^{22}$ Note the use of the imperfect, durative aspectualisation (' $\mathrm{era}$ ') to depict an originary situation or essence that erases change, eventfulness and histor(icit)y, as in the 'once upon a time' opening of fairy tales: as Foucault (2002) has argued, utopias, unlike heterotopias, allow for the very emergence of fables because they are the very substance of the fabula. In the full verbal sequence, the utopianism of the event (her birth) is visually marked as blue -the colour of the utopian sea is the colour of his first vision of herand aspectualised in the perfective-inchoative mode ('nació', 'vi'): Alex nació azul. Era perfecta, desde el primer momento que la vi, perfecta.' The colour blue is also the dominant colour in the film's palette. ${ }^{23}$ Queer utopia names here a politically specified version of utopia, the result of a specific articulation between the universal (narratives of origin and telos) and the particular (Alex's body and discourse), that is to say, the work of specification that the film, through Alex's process of subjectivation, symbolically performs.
} 
free itself from the two given temporal narratives described above, through the immanent, irreducible spatiality that only queer teen relationality, positive and negative affects and the heterotopian logics of the beside are able to afford to Alex.

3. 2 Linguistic heterotopias (framing the intersex body) and queer relational agency Relational affects -negative and positive- are crucial for this discussion of the intersex body as utopian or heterotopian because they provide the necessary context for situated textual interpretation. Key interpretative cues are given by film dialogue data, in addition to the analysis of visual language and cinematic space (i.e. shots) provided in the previous sub-section (3.1.): the purpose of what follows is to further substantiate such analysis of the heterotopian intersex body in the context of the relational, affectladen queer utopias that are not 'a given' (as 'naturally' inscribed in the former), but symbolically worked through the film by means of use of visual language and verbal speech.

In the one of scenes mentioned above, while Alex is bathing on her own in the sea, her genitalia are covered by her wearing shorts, a cue for interpreting Alvaro's -and through him, the audience's- scanning and reading (of) her body is partly given by the dialogue that takes place between the teens in the woods immediately following the latter two intersex body scenes.

- Alvaro: Alex! [agitated, chasing her] (hhh) explicame ¿Vos no sos...?

- Alex: Soy las dos cosas

- Alvaro: Pero eso no puede ser

- Alex: ¿Vos me vas a decir a mí qué es lo que puedo o no ser?

- Alvaro: Pero te gustan los hombres o las mujeres?

- Alex: No sé [...] Perdoname lo que te hice.

Alvaro: No, no me hiciste nada (.) No me molestó (.) Me gustó Alex: ¿En serio?

Alvaro: Sí 
Alex: A mí también

Alvaro: ¿En serio? (.) Terminemos No terminamos

Alex: No voy a hacerlo con vos! [Alex aggressively pushes Alvaro away] Alvaro: ¿Por qué?

Alex: Yo quiero otra cosa

Alvaro: Yo también quiero otra cosa

Alex: ¿Ah sí? ¿Qué querés?

Alvaro: Vos ¿qué querés? (.) Alex, va a ser nuestro secreto

Alex: Mentira!

Alvaro: No le cuento a nadie

Alex: Mentís (.) Andá decile a todos que soy un monstruo [Alex runs away]

(10)

"-Alvaro: Alex! [agitated, chasing her] (hhh) please explain to me

You're not...?

- Alex: I am both

- Alvaro: But that cannot be possible

- Alex: You are going to tell $m e$ what [it is that] I can or cannot

be/become?

- Alvaro: But do you like men or women?

- Alex: I don't know [...] I'm sorry for what I did to you.

- Alvaro: No, you didn't do anything [bad] me (.) It didn't upset me (.) I liked it

- Alex: Really? [Are you being serious?]

-Alvaro: Yes

- Alex: Me too [I liked it too]

-Alvaro: Really? [Are you being serious?] (.) Let's finish We didn't

come

- Alex: I'm not gonna do it with you! [Alex aggressively pushes Alvaro away]

-Alvaro: Why?

- Alex: I want something else

-Alvaro: I want something else too

- Alex: Oh really? What do you want?

-Alvaro: And you What do you want? (.) Alex, this will be our secret

- Alex: Lies!

- Alvaro: I won't tell anyone

- Alex: You're lying (.) Go and tell everyone that I'm a monster" [Alex runs away]

In Alvaro's use of the impersonal form in the second turn cited above ("But that cannot be possible"), he is expressing an impossibility that marks not only the intersex body as heterotopian, but the heterotopian as undermining language from within, its very 
'syntax': the heterotopian impossibility, in real-existing linguistic categories, of naming 'both this and that' (Foucault 2002: xix). This is Foucault's linguistic concept of heterotopias, inspired by Borges, in The Order of Things, which has been insightfully used by Elliot and Purdy in their analysis of filmic heterotopias:

'Heterotopias are disturbing, probably because they secretly undermine language, because they make it impossible to name this and that, because they shatter or tangle common names, because they destroy "syntax" in advance, and not only the syntax with which we construct sentences but also that less apparent syntax which causes words and things (next to and also opposite to one another) to "hold together", (Foucault 1970, in Elliott \& Purdy 2006: 275).

Alex's response -the 'impossible' double participation ["I am both"] that characterises linguistic heterotopias- is clearly neither the space of the sexually ambiguous - the androgynous- nor that of the utopian -the perfect blending or 'mixture' of the sexes in the god(ess)-like body of the transcendentally unitary 'hermaphrodite'. Far from utopian, this initial interactional construction of Alex's intersex body has, on the contrary, the heterotopian status of the 'unthinkable'. ${ }^{24}$

This 'impossible' double participation [Soy las dos cosas/ "I am both"], as verbally affirmed by Alex and heard by Alvaro [eso/that], is clearly neither the space of myth nor that of utopia, which are two different fables of perfection. If the myth of the hermaphrodite/androgynous can be construed as the primordial wholeness and perfection through an imagined or alleged harmonic (re)union of the sexes (a fable of origins/past), the utopian reading of the hermaphrodite's biology points to the perfection attributed to the blending or 'mixture' of the sexes in a god(ess)-like body: s/he has

\footnotetext{
${ }^{24}$ For a clear explanation of this crucial distinction between linguistic/discursive heterotopias and linguistic/discursive utopias, see Foucault (2002: xviii-xix).
} 
been given in bisexuality her/his 'true sex', only to be discovered because it has already been transcendentally given ${ }^{25}$ to him/her (a teleological fable of the present driven by the future).

Alex's 'double participation' corresponds, on the contrary, to the heterotopian and the present. Indeed, from a conversational viewpoint, her body features in this scene as 'monstrous' double participation of heteroclite, and already classified, 'elements' in one real body. Hence, this double participation is foregrounded by Alex's own discourse as fundamentally heterotopian: a body -only a sexual 'subject'-in-process at its very inception - that is predicated as 'both' [male and female], hence, an adding of two biological attributes or 'things', in the sense that these sex-discursive attributes have not yet crossed the symbolic threshold of a condition, and hence, of subjectivisation and being, queer or otherwise. This heterotopian construction is Alex's response to Alvaro's impersonal, objectifying framing ('eso'='that') of Alex as an unviable and unthinkable 'a-subject' (Butler 1991), clearly pointing to the abject. If for her father her body was a biological utopia ('Alex was born blue. She was perfect, from the very first moment that I saw her, perfect'), Alex's lived experience is that of a real heterotopia, a material and discursive one.

Despite the marking out of the linguistic space of the unthinkable as 'impossible' (Alvaro’s eso/"that”), Alex’s body exists immanently -it is existentially part of our world with its planes of immanence. However, it does not seem to make

\footnotetext{
${ }^{25}$ The misleading 'apoliticism' of such conceptions of the intersex body are not only erroneous but politically dangerous, insofar as they do not do justice to intersex people. These kinds of utopianism are mis-politicising in the sense that Laclau (2001) discusses the category of 'utopia' as misleading fables that (mis)represent collective subjects and essentialise their subjectivities as beings or as partial totalisations condensed in nameability: provisionally unified identities in their processes of becoming, and even if engaged in multiplicity and fluidity. Normative or biological utopias do so by ideologically misleading us to construe subjectivities as if they were given by God (or 'Nature'), rather than a result of complex symbolic work and contextualised processes of overdetermination.
} 
sense within the immanence of our binary-gendered linguistic categories: this is a linguistic impossibility that, being specific to heterotopias, points to a spatial juxtaposition (las dos cosas/“both") that has not yet taken place in the "non-place of language'. It is in this sense that Alex's body is co-constructed in these filmic interactions that reflect the lived experiences of the queer teens rather than the adults' discourses, as a fundamentally heterotopian body. Let us recall here that linguistic heterotopias, for Foucault, do not refer to any mixture, but to very specific ones, as they have to fulfil two conditions. On the one hand, those mixtures must affect both reality and imagination: it is only by 'contaminating' them both (e.g. sex and fantasy/desire) that they become 'dangerous' insofar as they destroy our very systems of classification by contagion of what should remain separate criteria (even if the members of those classes are mixed beings; e.g. a siren or a mixed raced person are not dangerous). On the other hand, the heterotopian quality of 'monstrosity' has to affect a 'real body' -not just circumscribed to imaginary, fantasy worlds- thus disturbing the very syntaxbecome-semantics that 'hold together' words and things ${ }^{26}$, that is, the very rationale of their containment. In other words, the heterotopian is 'the monstrous' in the real, and involves mixtures that could be 'dangerous' to our thought, to our 'order of things' established by language and its established semantic association through dominant syntax.

Alex, for her part, responds to Alvaro's impersonal comment with a rhetorical question in the personal form, thus re-introducing the enunciated enunciation (Courtés, 1997: 367-394) through an operation of enuncive embrayage (372-374) (i.e. first and second personal pronouns and verb forms), and re-establishing the (personalised) axis

\footnotetext{
${ }^{26}$ For example: vagina, clitoris + breasts $=$ 'female'; penis, testicles + chest $=$ 'male'.
} 
of communication within the fictional narrative enoncé: that is, by switching back from histoire to discours, as in the first two turns of the data (10) transcribed above ${ }^{27}$ :

- ¿Vos me vas a decir a mí qué es lo que puedo o no ser? [personal form] - Pero te gustan los hombres o las mujeres?

- "Are you going to tell me what [it is that] I can or cannot be/become?"

- But do you like men or women?"

Contextually and interactionally, this is particularly important because it implies that their conversation is now switching back to Alvaro's first turn that had initiated this interaction as a piece of discours which, from an actorial viewpoint, is entirely 'embrayagé' (Courtés 1997: 369-374), through an explicitly personalised footing: 'please explain to me [.] You're not...?'. Alvaro had put Alex in a discursive position in which she 'ought' to give an account of herself to him of 'not being' what he had thought s/he was (i.e. of her sexual being), an imposed position that unequally requires an agency that is not equivalently required from Alvaro's socially assigned position as sexual being. In the immediately subsequent turn, Alex's critically responds to Alvaro's previous impersonal formulation by introducing the instance of agency ('I' and 'me') to the order of being and processes of becoming (Giffney 2008). The matter of discussion -the 'topic' in terms of enunciative and argumentative analysis- is neutral (Alvaro's eso/"that", and Alex's qué/"what" or lo que/"that"), but it obviously implies, in the context of their interaction, female and male gender and/or sex (sexual difference). However, this 'gender/sex topic' is interestingly heard by Alvaro in the following line

\footnotetext{
${ }^{27}$ Particularly switching back to Alvaro's first turn that had initiated this interaction as a piece of discours which, from an actorial viewpoint, is entirely 'embrayagé' (Courtés 1997: 369-374), through an explicitly personalised footing: 'please explain to me [.] You're not...?'. Alvaro had put Alex in a discursive position in which s/he 'ought' to give an account of herself to the former of 'not being' what Alvaro had thought s/he was (i.e. of her sexual being).
} 
as sexual orientation introducing the latter as a possible deciding factor for the sex/gender issue: Alvaro is, thus, expressing his own anxieties about his masculinity. Alvaro is the object of Alex's sexual drive: from the very beginning, she invites him to have sex with her, and later on, she penetrates him.

It is interesting to analyse here the interrelatedness and mutual implication between gender/sex and sexuality/sexual orientation. Initially what Alvaro had felt the previous day but not quite seen (as a voyeur) in the sea bathing scene, is 'not woman' (vos no sos...?/ "you're not...?”), but half way through the conversation, in an attempt to decode Alex's sexual being as well as his, Alvaro has recourse to redirect the topic of the conversation from sex/gender to desire. Such a conversational move is significant because it presupposes a change of theme/topic rather than rheme: he prompts the pair to leave the [gender] identity topic and move to that of sexual orientation. By embedding the change of topic through an adversative conjunction [pero/“but"], what Alvaro is doing here is introducing (sexual) desire and eroticism to an otherwise adultcloset-originated gender 'trouble'. By doing so, he is effectively displacing the familydefined secret around sex/gender and the sex-gender's repressive configuration through binaries and boundaries, to what the pair of adolescents actually shared and enjoyed: lived sexuality brings about teen-teen relationality.

The dialogue frames the reading of the (in)visible (intersex) body -the perceptually apprehended but not yet intelligible nor recognisable (Butler 2010) eso/"that"' - in terms of what is (socially and/or personally) possible. It signals a passage between the (normative) universal interrogator who interpellates from the impersonal voice of the norm and defines the boundaries of what is possible to a singular response that comes from the lived experience of an intersex bodied adolescent: 
Alex's response above evidences not only singularity but also the fact that she manages to articulate some interactional agency. Alex ends this conversation by providing a derogatory term that is intended to name a body that is socially perceived as unviable and impossible, and by extension, to label herself in a shameful, insulting manner: monstruo/“monster". Interactional nameability is key here to the development of personal agency: from this inter-phobic naming onwards, Alex embarks on a 'journey of self-discovery'. Such a journey moves her 'through the "desert of nothing"” (Leap 1996: 136-139; 1999: 264) that conceals her sexual being under the signifier 'girl', in a similar way as derogatory homophobic naming is a key resource for gay adolescents in their processes of coming out as it has been studied by Leap (1999: 266). By the end of the film Alex decides to stop taking the feminising hormones, and does not buy into the gender/sex binary by stating that maybe nothing needs to be changed in her own body.

This framing of what is conceived as (im)possible within a singular passage from the universal to the really-existing particular-closeted intersex Alex, a living figure that is shown as bearing a material, yet not an ontological status (Butler 2010) ${ }^{28}$ is what allows for a reading of the intersex body and sexuality onscreen as a fundamentally heterotopian one. What gives the intersex body its queer utopian symbolic meaning is not to be found in its bare self, but in the sea as the recurrent context in which the film presents its (half)nudity as well as her relational encounters with her teenage peers: it is the sea -as background first, as natural and interpersonal environment later- what confers Alex's (half)naked body a sense of queer symbolic utopianism.

\footnotetext{
${ }^{28}$ I am drawing here on Butler's (2010) distinction between the 'living' and recognised 'life/lives'.
} 


\section{Conclusions}

By way of conclusion, in $X X Y$, Alex's and Alvaro's shame-originated subjectivities and the subsequent processes of performativity and subjectivation that they open up, cannot be fully and semantically contained by articulated language. This argument is extendable, as I hope to have demonstrated, to Glue and El último verano..., insofar as the three films analyzed here focus on shame as a pivotal affect configuring both language and what exceeds it. Even if constitutive affects such as shame are revealed and negotiated to a certain extent by speech -as we have explored in some detail with reference to verbal data from the movies' dialogue- affect also marks and is produced at the very limits of articulated (audio-visual) language. These affective spaces are liminal: they are not contained within semantically decodable language or images, but inbetween the articulated and the non-articulated, in-between the semantic ('sense') and the semiotic ('form') (Benveniste 1971: 118-130; 1974: 21-22, 43-66; Agamben 1993: 60-64), or in phoné as the space that is inbetween and in excess of lexis (Lyotard 1997).

In the fictional stories analyzed in this article, shame and shaming find their relational expression in the child and teen protagonists' acting out of their respective traumatic experiences and associated antagonisms: negative affects such as shame and shaming can thus be read as the expression of their queer selves' antagonistic core. Shame as the prevailing affective meaning in these films works, however, at the very limits of articulated language by marking the latter's limitations: in these liminal spaces, shame triggers queer teen subjectivation as a set of transformation processes that are, first and foremost, spatial and spatializing: they generate -through the workings of negative and positive affects- a new, creative and transformative inner space that 
anticipates but does not yet articulate the queer self. Ultimately, what can bring about their agency are the positive affects implied in non-(gender)-normative infantile sexuality, (queer) teen-teen bondings, shared joy and solidarity.

\section{References}

Author's address

Guillermo Olivera

Literature and Languages

University of Stirling

Stirling FK9 4LA

Scotland, United Kingdom

guillermo.olivera@stir.ac.uk 